UDC 519.6

\title{
Comprehensive method for classification of layers and Nissl-stained cells of mice brain cortex on the basis of layered statistics of cells descriptors *
}

\author{
S.A. Nosova, V.E. Turlapov ${ }^{* *}$ \\ National Research Lobachevsky State University of Nizhni Novgorod, Nizhny Novgorod, Russia
}

A comprehensive method for automatic detection layers of the cortex and brain cells from images of mouse cortex sections stained according to Nissl is proposed. A table is given linking the values of 11 descriptors of 4 types of brain cells with the number of the cortex layer. Since the reconstruction of the boundaries of layers, the method allows to detect astrocytes and 3 types of neurons. After cell localization, which plays of importante role for algorithmization, the segmentation procedure defines the cell boundary via the Canny method and uses the descriptors' values for the layer.

Keywords: image processing; optical microscopy, nissl-staining; mouse brain cortex; segmentation; layers by Broadman; classification; neuron; astrocyte; Gauss-filtering; math morphology; Canny method; ray-method

Introduction. Rating staining according to Nissl in brain study by optical microscopy makes actual imaging automation for these studies, and this urgency grows with intensity of research and a variety of methods, as data storage remaining unprocessed or under-researched, up to recent years. So in the article [1], devoted to the segmentation of pyramidal neurons, the watershed method is used. In [2], cell segmentation is carried out on the basis of machine learning by the method of a random forest. An algorithm based on the normalized section of the graph is described in [3]. In [4] the ANRA method is proposed, which is based on machine learning methods and has good accuracy. The task of detecting the boundaries of layers is solved in [5] and [6] as a separate problem on the basis of mouse atlases.

The aim of this work is to create and test a complex method of classifying brain cells that takes into account in an explicit form the real connections of some possible cell descriptors with the layer in which they are located. These microscopes are provided and marked out by the State Medical Academy of Nizhny Novgorod.

Layered statistics of descriptors of mouse cortex cells. According to Brodman the mouse cortex consists of 6 layers (layers 2 and 3 are considered inseparable). To solve the problem of classification of cells (neurons and astrocytes), statistics on their shape and density distribution inside

\footnotetext{
* The research is supported by the Federal Target Program of the Ministry of Education and Science of the Russian Federation, contract 14.581.21.0016 (RFMEFI58115X0016).

${ }^{* *}$ E-mail: vadim.turlapov@itmm.unn.ru
} 
the cell (based on the marking by a specialist, fig. 4 (2)). Table. 1 shows the characteristics of different brain cells are shown depending on the layer.

Table 1. Characteristics (descriptors) of the shape of cells depending on the layer (Astr. astrocytes , PN - pyramidal neurons, SN - stellate neurons; MLN - molecular layer neurons)

\begin{tabular}{|c|c|c|c|c|c|c|c|c|c|c|c|c|}
\hline 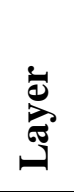 & $\bar{\Xi}$ & 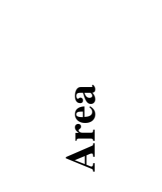 & 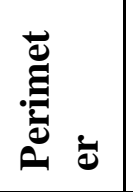 & & 可 & 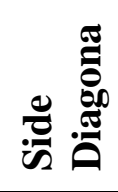 & 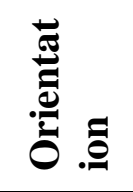 & 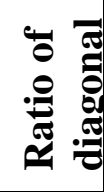 & ڤ્ٌ & 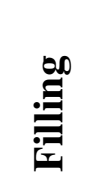 & ì & 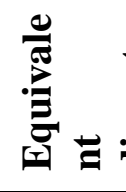 \\
\hline \multirow[t]{3}{*}{ I } & Astra. & 139.00 & 55.80 & 0.70 & 17.60 & 11.29 & 97.01 & 1.58 & 0.58 & 0.91 & 0.86 & 13.29 \\
\hline & MLN & 419.25 & 88.58 & 0.67 & 32.18 & 19.52 & 90.22 & 1.65 & 0.66 & 0.92 & 0.95 & 22.96 \\
\hline & $\mathrm{SN}$ & & & & & & & & & & & \\
\hline \multirow{4}{*}{$\begin{array}{l}\text { II- } \\
\text { III }\end{array}$} & & & & & & & & & & & & \\
\hline & Astra. & 278.30 & 65.60 & 0.71 & 25.41 & 16.09 & 113.06 & 1.68 & 0.74 & 0.94 & 0.96 & 18.50 \\
\hline & MLN & 781.02 & 118.60 & 0.72 & 43.18 & 25.37 & 81.54 & 1.74 & 0.70 & 0.94 & 0.95 & 31.38 \\
\hline & $\mathrm{SN}$ & 1171.25 & 134.18 & 0.77 & 42.55 & 35.55 & 115.94 & 1.20 & 0.81 & 0.96 & 0.94 & 38.48 \\
\hline \multirow[t]{3}{*}{ IV } & Astra. & 369.92 & 79.51 & 0.72 & 29.60 & 17.63 & 98.15 & 1.72 & 0.75 & 0.95 & 0.96 & 21.63 \\
\hline & MLN & & & & & & & & & & & \\
\hline & SN & 793.38 & 111.30 & 0.75 & 38.29 & 26.79 & 85.39 & 1.45 & 0.78 & 0.96 & 0.95 & 31.33 \\
\hline \multirow[t]{3}{*}{$\mathbf{V}$} & Astra. & 340.56 & 72.74 & 0.73 & 26.65 & 17.59 & 102.02 & 1.53 & 0.76 & 0.95 & 0.96 & 20.78 \\
\hline & MLN & 1456.23 & 165.32 & 0.68 & 56.61 & 37.75 & 89.80 & 1.55 & 0.66 & 0.92 & 0.94 & 42,44 \\
\hline & $\mathrm{SN}$ & 1375.83 & 146.14 & 0.76 & 48.89 & 36.39 & 85.55 & 1.38 & 0.79 & 0.97 & 0.95 & 41.49 \\
\hline \multirow[t]{3}{*}{ VI } & Astra. & 322.85 & 70.33 & 0.71 & 25.63 & 16.97 & 89.75 & 1.55 & 0.75 & 0.95 & 0.96 & 19.61 \\
\hline & MLN & & & & & & & & & & & \\
\hline & $\mathrm{SN}$ & 1786.98 & 169.24 & 0.75 & 55.31 & 42.58 & 93.00 & 1.31 & 0.78 & 0.96 & 0.94 & 47.24 \\
\hline
\end{tabular}

Fig. 1-3 show the normalized histograms of the image intensities for the labeled regions of astrocytes , pyramidal and stellate neurons, depending on the layer of the cortex .

Detection of cortex layer boundaries. Data used for pre-processing of the histogram equalization algorithm, described in [7] - obtain image $E Q_{-} I$. Fig. 4 (4) shows the result of applying this algorithm.

Table 2. The ratio of the thickness of the layers of the cortex to the thickness of the cortex as a whole

\begin{tabular}{|c|c|c|c|c|}
\hline I & II-III & IV & V & VI \\
\hline 0,09 & 0,25 & 0,08 & 0,22 & 0,36 \\
\hline
\end{tabular}


We calculate the density function for the image $D L(i, j)$, normalized density function $\operatorname{NDL}(i, j)$, we find the average value of the density function, using the following formulas:

$$
\begin{aligned}
& D L(i, j)=\frac{1}{\min (M-1, j+k)-\max (0, j-k)+1} \sum_{y=\max (0, j-k)}^{\min (M-1, j+k)} E Q_{-} I(i, y), \\
& 0 \leq i \leq N-1,0 \leq j \leq M-1,0<k \leq N-1 ; k \text { is the tunable parameter, } \\
& N D L(i, j)=\frac{D L(i, j)}{\sum_{i=0}^{N-1} D L(i, j)} \quad \overline{N D L}(j)=\frac{1}{N} \sum_{i=0}^{N-1} N D L(i, k) .
\end{aligned}
$$

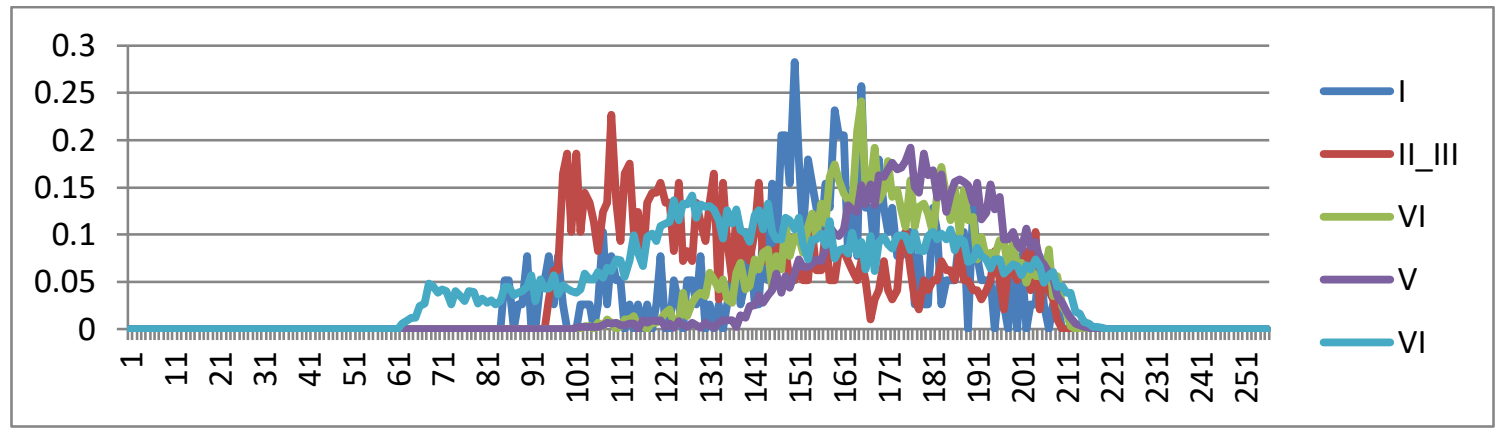

Fig. 1. Nomalized histograms of astrocytes depending on the layer of the cortex

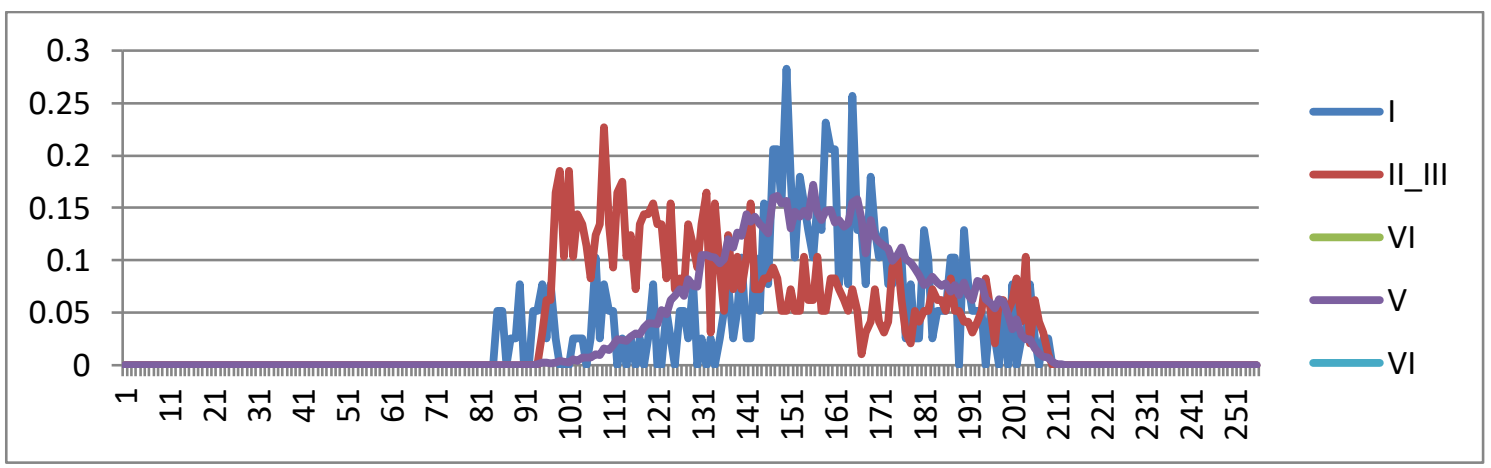

Fig. 2. Nomalized histograms of pyramidal neurons for layers of cortex

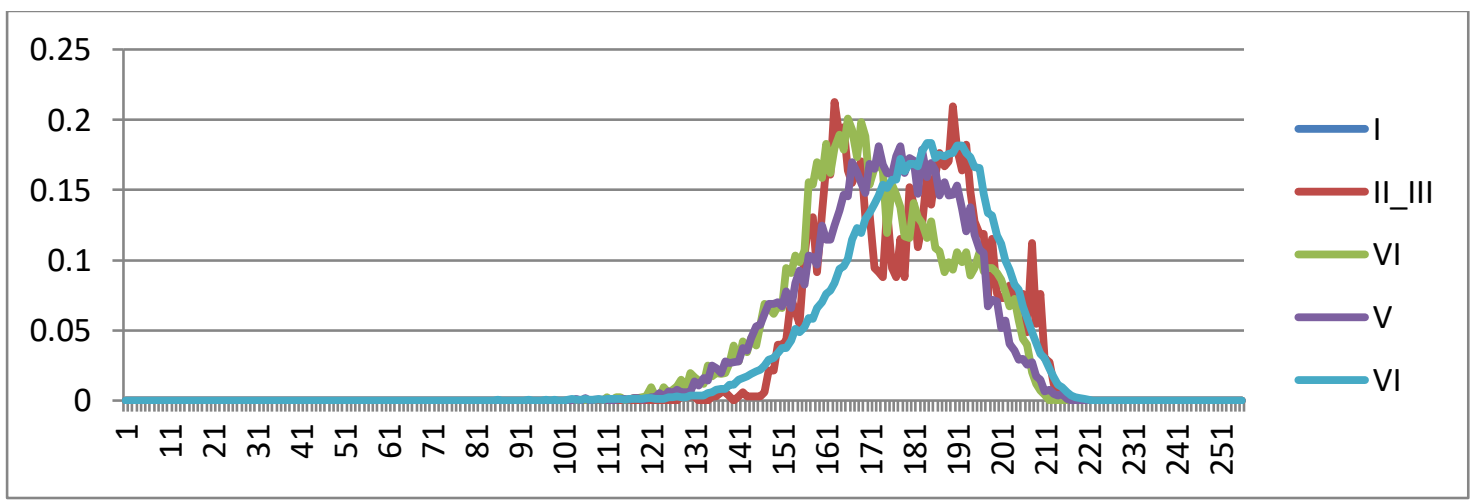

Fig. 3. Nomalized histograms of stellate neurons for cortex layers 


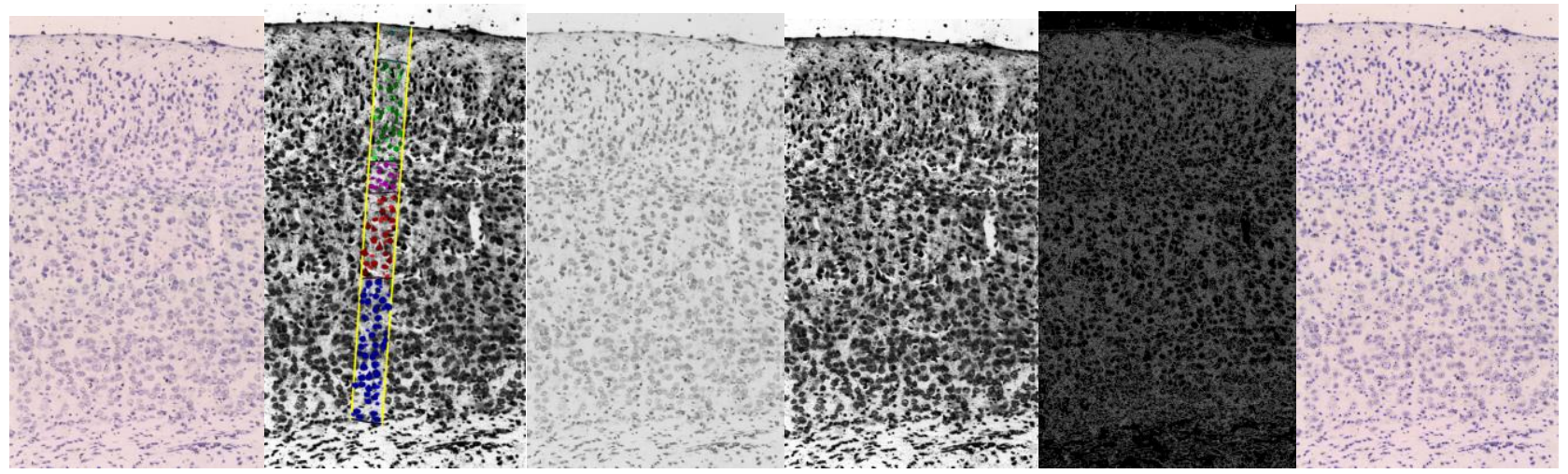

Fig. 4. From left to right, from top to bottom: 1 - the original image, 2 - the marked data, 3 - the image in shades of gray, 4 - the increase in contrast of the original image, 5- the result of boundary detection by Canny method, 6 - the result of point detection algorithm

The upper and lower boundaries of the cortex in each column of pixels are calculated as follows:

$$
\begin{aligned}
& \text { upperBorder }(j)=\min _{0 \leq i \leq N-1} i, N D L(i, j)>\overline{N D L}(j)+k 1, \\
& \text { lowerBorder }(j)=\max _{0 \leq i \leq N-1} i, N D L(i, j)>\overline{N D L}(j)+k 2, \\
& 0 \leq j \leq M-1 ; k 1 \text { и } k 2 \text { are the tunable parameters. }
\end{aligned}
$$

Thus, upperBorder (j), lowerBorder ( $j$ ) uniquely determine the finding of the upper and lower boundary of the cortex layers according to Brodman (fig. 5). Separators between intermediate layers are calculated on the basis of the statistics given in table 2. Fig. 7 shows the final separation into layers is shown in.

Detection of all cells as neurons. Detection consists in finding the centers of cells and estimating the radius of cells. The algorithm for detecting all cells as neurons was published in [8].

Registration of all cells as neurons. At this stage, we have $p(l)$ points (all so far detected as neurons) and estimates of the radii of the obtained cells $r(l)$. The segmentation algorithm based on ray methods consists of the following steps (perform for each 1 ):

1. To form on the image Canny_I $(i, j)$ square $\operatorname{rect}(l)$ with the center in $\mathrm{p}(l)$ side $1.5^{*} \mathrm{r}(l)$.

2. Generate a set of rays from $\mathrm{p}(i)$ to the boundaries rect $(l)$.

3. For each ray: find the intersection of the ray with the boundary to Canny_I $(i, j)$ closest to the center rect $(i)$ or to the rect $(l)$ boundary. Mark the resulting point as the boundary of the object. 


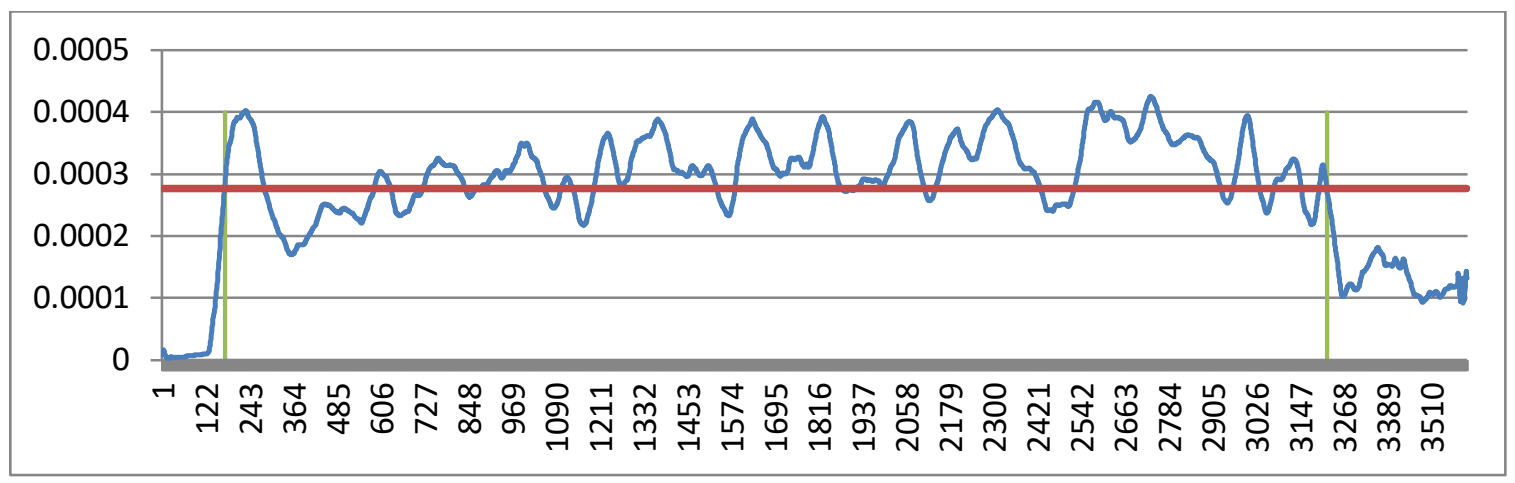

Fig. 5. The image density function for one of the image columns, its average value, the position of the upper and lower boundaries of the cortex layers

Fig. 6 shows that the boundaries turn out to be torn. In order to get a smoothed border of the cell, the operation of mathematical morphology «opening» is applied with the tool radius equal to 5.

As a result, we obtain a cell with a smooth contour (fig. 6, right-hand column).
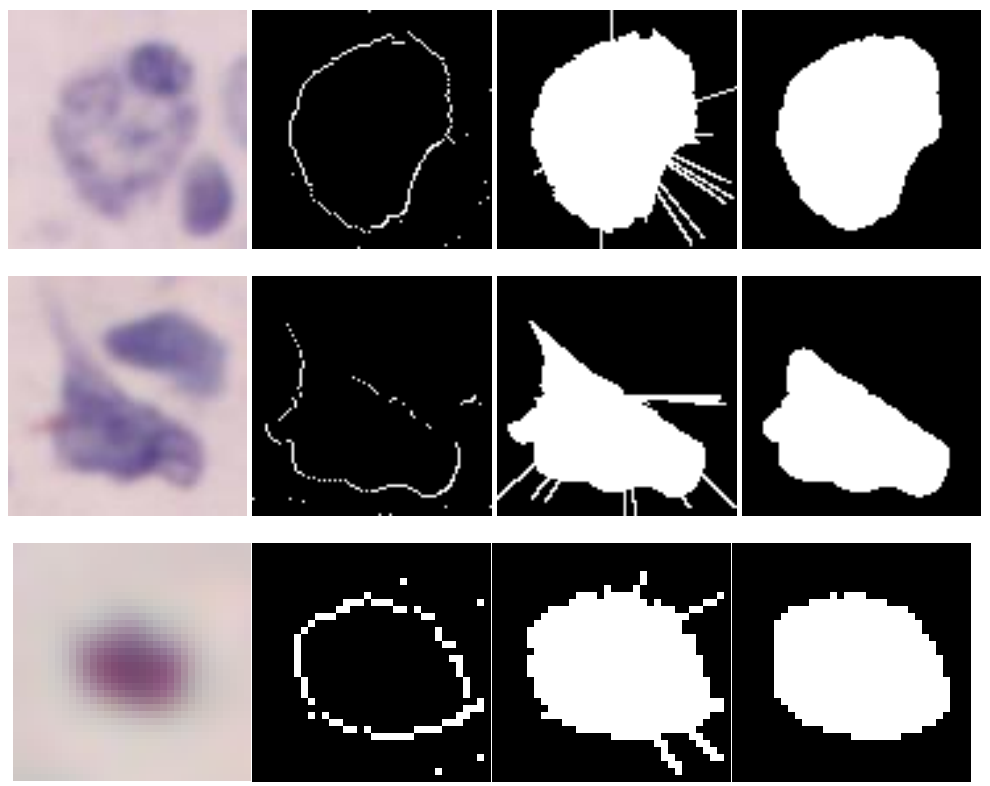

Fig. 6. Examples of cell boundary detection (from left to right): the initial image of cells; found boundaries; a region filled by the found boundaries; the filled region after the application of the morphological opening operation $(r=5)$

Classification of neurons. We examine the shapes of our objects in 11 shape parameters and in a histogram (for an image in shades of gray). To calculate the similarity factor, we use the following formula: 


$$
\begin{aligned}
& \operatorname{similarity}(j)=\alpha \sum_{k=0}^{10} \operatorname{koef}(\mathrm{k}) * \min \left(\frac{\text { model_shape }(j, k)}{\text { object_shape }(k)}, \frac{\text { object_shape }(k)}{\text { model_shape }(j, k)}\right)+ \\
& \beta\left(1-\frac{\sum_{k=0}^{255} \mid \text { model_hist }(j, k)-\text { object_hist }(k) \mid}{\sum_{k=0}^{255} \mid \text { model_hist }(j, k)+o b j e c t_{-} h i s t(k) \mid}\right)
\end{aligned}
$$

where $\operatorname{similarity}(j)$ is the degree of similarity of the object to the cells of class $j$; model_ shape parameters of cell forms of different classes (table 1); object _ shape - parameters of the form of the object; model_ hist - histograms for cells of different classes (fig.1,2, 3);object_ hist - histogram of objects; $\alpha, \beta$, koef ( $k$ ) - tuning parameters, due to which it is possible to vary the importance of one or another characteristic.

For each cell region reg $(i)$, if it is in one of the layers of the cortex, calculate:

1. The number of the layer to which reg $(i)$ belongs.

2. Descriptors in table 1 and measure the similarity (similarity) with a cell region classes cells that layer.

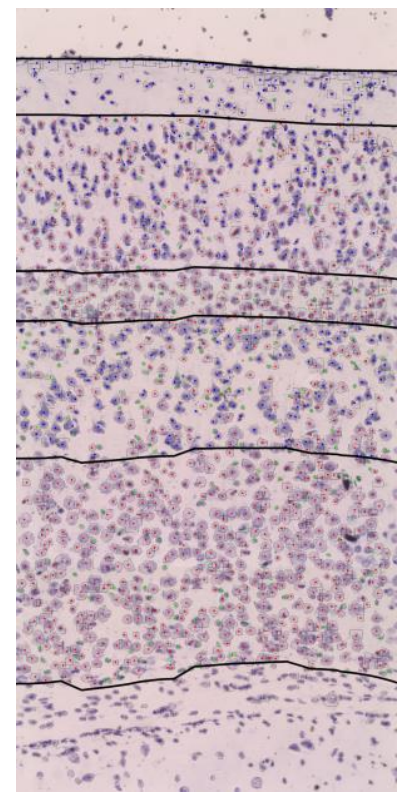

Fig. 7. The result of the algorithm

Classify the region to that class, the degree of similarity with which is greater.

Conclusion. A complex method is proposed that starts the solution of the problem of automatic segmentation and classification of sections of the mouse brain, colored according to Nissl, from the detection of cortex layer boundaries. In this case, the outer boundaries of the layers are detected and the statistics of the ratio of the layer thickness in the cortex are used (table 2). 
In the part of the task of defining the boundaries of layers, the algorithm has results comparable to algorithms based on mouse brain atlases $[5,6]$ and using machine learning methods [9].

In the classification of brain cells, the phase of their detection (position and size determination) is identified, which is of fundamental importance for the algorithmization of the method. Further classification is based on the detection of cells of circuit 11 based descriptors for the cell with a predetermined contour and use classification table descriptor values astrocyte and neurons 3 types for each of the layers of the cortex, obtained by statistical processing of the data of sections, marked by a specialist-morphologist. The result of the method is shown in fig. 7.

As a next step, it is useful to expand the scope of the experimental material, which verified the method and the statistics shown in the work.

\section{References}

1. 1. Kolodziejczyk A., Habrat (Ladniak) M.Piorkowski A. Constructing software for analysis of neuron, glial and endothelial cell numbers and density in histological Nissl-stained rodent brain tissue. Journal of medical informatics \&technologies, Vol. 23, pp. 77-86, 2014.

2. Das S., Keyser J., Choe Y. Random-forest-based automated cell detection in KnifeEdge scanning Microscope rat Nissl data. Proceedings of the International Joint Conference On Neural Networks. 2015. DOI:10.1109/IJCNN.2015.7280852

3. He Y., et al. ICut: An integrative cut algorithm enables accurate segmentation oftouching cells. Scientific Reports 5(12089), DOI: 10.1038/srep12089, 2015.

4. Inglis A., et al. Automated identification of neurons and their locations. J. Microsc., 2008 June. 230 (Pt 3), pp. 339-352., 2008.

5. Allen Brain Atlas. Data Portal, 2004-2006. (http://mouse.brain-map.org/)

6. Brain maps, 2005 (http://brainmaps.org)

7. Сайт документации библиотеки OpenCV (http://docs.opencv.org)

8. Nosova,S., Snopova,L., Turlapov,V.. Automatic detection of neurons, astrocites, and layers for Nissl staining mouse cortex. Journal of WSCG, Vol.25, No.2, pp. 143-150, 2017.

9. Senyukova, O.V., Lukin, A.S. \& Vetrov, D.P. Automated atlas-based segmentation of NISSL-stained mouse brain sections using supervised learning. Programming and Computer Software, Vol. 37, No. 5, pp.245-251, 2011.

\section{Authors:}

Turlapov Vadim Yevgen'yevich, Professor, Doctor of Technical Sciences, National Research Lobachevsky State University of Nizhni Novgorod, (Gagarin Ave., 23, Nizhny Novgorod, Russia)

Nosova Svetlana Aleksandrovna, post-graduate student, National Research Lobachevsky State University of Nizhni Novgorod, (Gagarin Ave., 23, Nizhny Novgorod, Russia) 
УДК 519.6

Комплексный метод классификации слоев и клеток кортекса мозга мыши, окрашенных по Нисслю, на основе послойной статистики дескрипторов клеток *

\section{С.А. Носова, В.Е. Турлапов ${ }^{* *}$}

Нижегородский государственный университет им. Н.И. Лобачевского, Нижний Новгород, Российская Федерация

Предложен комплексный метод для автоматического детектирования и классификации слоев коры и клеток мозга по изображениям срезов кортекса мыши, окрашенных по Нисслю. Построена таблица значений 11 дескрипторов 4 типов клеток мозга для каждого слоя кортекса, иллюстрирующая зависимость их значений от слоя. Метод начинается с реконструкции границ слоев для регистрации слоя каждой клетки. Регистрация далее определяет границу клетки, комбинируя метод Сanny, лучевой метод, матморфологическое открытие. Классификация астроцитов и 3 типов нейронов происходит по значениям дескрипторов текущего слоя.

Ключевые слова: обработка изображений; оптическая микроскопия; окрашивание по Нисслю; кортекс мозга мыши; сегментация; слои по Бродману; классификация; нейрон; астроцит; метод Сanny; лучевой метод

\section{Авторы:}

Турлапов Вадим Евгеньевич, профессор, доктор технических наук, Нижегородский государственный университет им. Н.И. Лобачевского, (603950, Россия, г. Нижний Новгород, проспект Гагарина, 23)

Носова Светлана Александровна, аспирант, Нижегородский государственный университет им. Н.И. Лобачевского, (603950, Россия, г. Нижний Новгород, проспект Гагарина, 23)

\footnotetext{
* Работа поддержана Федеральной целевой программой Министерства образования и науки РФ, контракт 14.581.21.0016 (RFMEFI58115X0016)

** E-mail: vadim.turlapov@itmm.unn.ru, svetlana.nosova@itmm.unn.ru.
} 